\title{
Effect of $\beta$ propiolactone on specific antibody measurements by ELISA
}

\author{
A E Agbarakwe, S A Misbah, H Griffiths, H M Chapel
}

\begin{abstract}
Serum samples from 30 HIV seronegative patients were treated with $\beta$ propiolactone (BPL) to determine whether BPL interfaces with ELISA for specific antibodies against protein and carbohydrate antigens. BPL had no discernible effect on specific antibody measurements by ELISA.

With the measuring need for specific antibody measurements in the management of HIV seropositive patients, it is reassuring that his laboratory safety measure does not impair the reliabiity of results.
\end{abstract}

(F Clin Pathol 1993;46:368-369)

The measurement of specific antibody titres against common protein and carbohydrate antigens forms an important part of the investigation of humoral immune deficiency. In addition to its devastating effects on cellular immunity, infection with HIV also leads to significant impairment of humoral immunity. Clinically, this has been reflected in the increasing burden of pyogenic infection with encapsulated bacteria in children and adults. ${ }^{1}$ As a result there is growing interest in the routine immunisation of all patients with AIDS with both pneumococcal and Haemophilus influenzae type $\mathrm{b}$ vaccines. ${ }^{2}{ }^{3}$ Indeed the United States Centers for Disease Control (CDC) currently recommends that all HIV seropositive subjects receive 23 valent pneumococcal polysaccharide vaccine. Consequently the number of requests for specific antibody measurement from these patients has increased considerably.

The practice of treating serum samples from HIV seropositve patients with $\beta$ propiolactone (BPL) to inactivate the virus has been adopted in some centres. Although the effect of BPL on other assays has been documented, ${ }^{4}$ we are unaware of any data on the effects of BPL on the measurement of specific antibodies by enzyme linked immunosobent assay (ELISA). We therefore investigated the effect of BPL on such an assay.

\section{Methods}

Sera from 30 HIV seronegative patients were assessed. One aliquot was assayed directly and $1 \mathrm{ml}$ of a second aliquot was treated with $2.5 \mu \mathrm{l}$ of neat BPL (Sigma Chemical Co) and then incubated for 60 minutes at room temperature before assay. Serum antibodies against tetanus toxoid, diphtheria toxoid, Haemophilus influenzae type b capsular polysaccharide (polyribosyl ribitol phosphate, PRP) and pneumococcal polysaccharide were measured using previously described ELISA methods. ${ }^{5-7}$ The antigens used to coat the ELISA plate were tetanus simple vaccine (Wellcome), diphtheria toxoid (Wellcome), 23 valent pneumococcal polysaccharide (Thomas Morson, pneumovax II) and HibPRP (supplied by BioMerieux). Both untreated and treated sera from each subject were measured on the same plate.

\section{Results}

Results were expressed in international units (IU) for both tetanus and diphtheria toxoid antibodies, arbitrarily as units per $\mathrm{ml}(\mathrm{U} / \mathrm{ml})$ for pneumococcal antibodies and as $\mu \mathrm{g} / \mathrm{ml}$ for anti-Haemophilus antibodies. All assays displayed good CVs for both intra- and interplate varation-tetanus $6 \%$ and $10 \%$, diphtheria $11 \%$ and $9 \%$, pneumococcus $12 \%$ and $10 \%$ haemophilus $7 \%$ and $17 \%$, respectively.

The upper limit of detection was $1 \mathrm{IU} / \mathrm{ml}$ for tetanus toxoid, $2 \mathrm{IU} / \mathrm{ml}$ for diphtheria toxoid, and $100 \mathrm{U} / \mathrm{ml}$ for pneumococcal antibodies. There was no upper limit of detection for the Haemophilis assay as all sera were titrated. The minimum detectable concentration of antibody by this technique was 0.01 $\mathrm{IU} / \mathrm{ml}$ for both tetanus and diphtheria antibodies, $1 \mathrm{U} / \mathrm{ml}$ for pneumococcal antibodies, and $0.15 \mu \mathrm{g} / \mathrm{ml}$ for Haemophilus antibodies. Sera with antibody concentrations above the upper limits of the tetanus, diphtheria and pneumococcal range were not assessed further.

Data correlation was carried out using linear regression analysis using the Amstrad OXSTAT statistical programme.

Linear regression analysis of results for untreated and treated sera showed a highly 


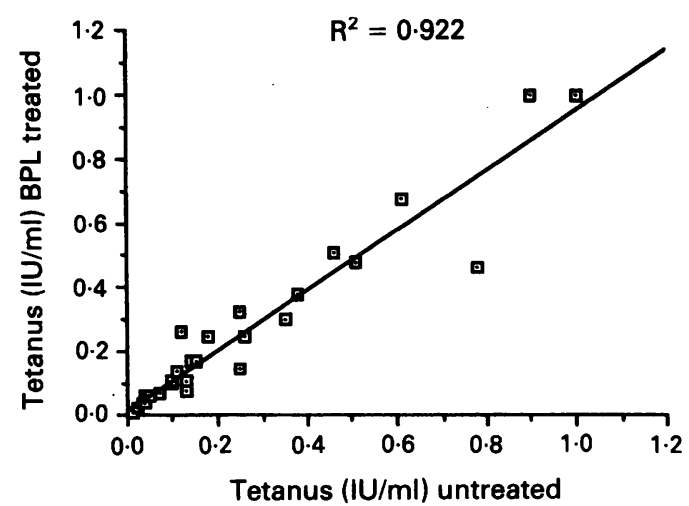

Figure 1

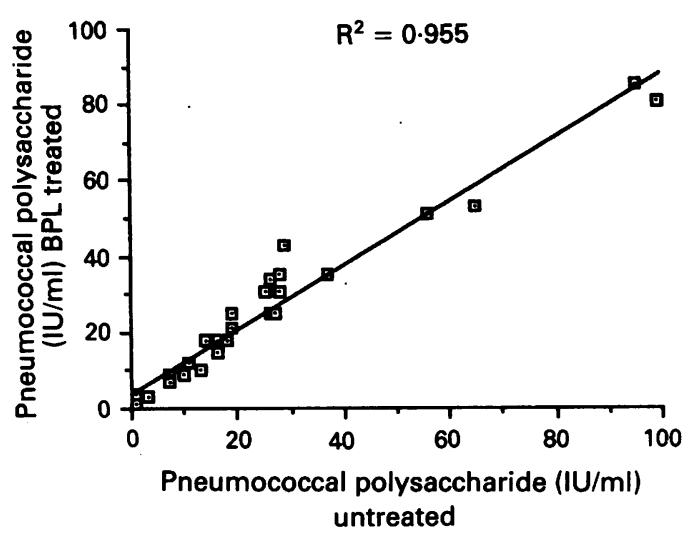

Figure 3

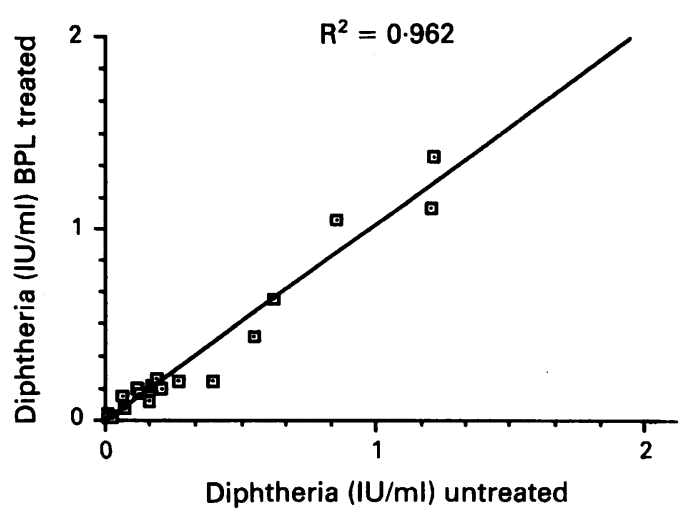

Figure 2

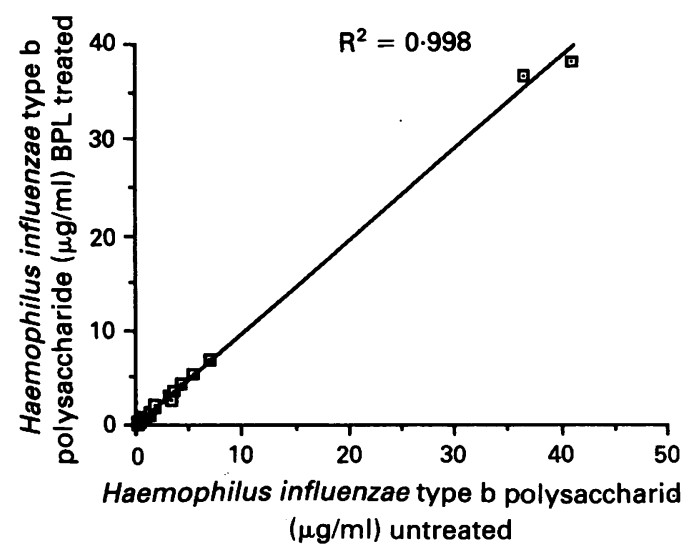

Figure 4

Figures 1-4 Correlation between BPL treated and untreated sera.

significant correlation for all four antigens (figs 1-4).

\section{Discussion}

$\beta$ propiolactone has long been recognised as a general virucidal, bactericidal, and fungicidal agent. ${ }^{8}$ It effectively inactivates HIV in vitro by inhibiting viral reverse transcriptase activity. We have shown that BPL in the concentrations used for in vitro inactivation has no discernible effect on the measurement of specific antibodies against both protein (tetanus and diphtheria toxoids) and carbohydrate (pneumococcal and Haemophilus capsular polysaccharides) antigens by ELISA. With the increasing need for such antibody measurements in the management of HIV seropositive patients, it is reassuring that this laboratory safety measure does not impair the reliability of results.
1 Janoff EN, Breiman RF, Daley CL, Hopewell PC. Pneumococcal disease during HIV infection. Ann Intern Med 1992;117:314-24

2 Steinhoff M, Auerback BS, Nelson KE, et al. Antibody responses to Haemophilus influenza type B vaccines in men with human immunodeficiency virus infection. $N$ Engl f Med 1991;325:1837-42.

3 Rodriguez Barradas MC, Musher DM, Lahart C, et al. Antibody to capsular polysaccharides of Streptococcus pneumoniae after vaccination of human immunodeficiency vinu infected subiects with 23-valent pneumococcal vaccine. F Infect Dis 1992;165:553-6.

4 Ball MJ, Spriges V, Sutton PM, Chapel H. Effect of beta propiolactone-an inhibitor of HTLV III/LAV activpropiolactone-an inhibitor of HTLV III/LAV activity - on immun

5 Booy R, Aitken SJM, Taylor S, et al. Immunogenicity of combined diptheria, tetanus and pertsis vaccine at 2,3 and 4 months versus 3,5 and 9 months of age. Lancet 1992;339:507-10.

6 Windebank KP, Faux JA, Chapel HM. ELISA determination of IgG antibodies to pneumococcal capsular polysaccharides in a group of children. 7 Immunol Methods 1987;104:143-8.

7 Booy R, Taylor SA, Dobson SRM, et al. Immunogenicity and safety of PRP-T conjugate vaccine given according to the British accelerated immunisation schedule. Arch to the British accelerated

8 LoGrippo GA. Investigations of the use of beta propiolactone in virus inactivation. Ann N Y Acad Sci 1960;83: 578-94. 
own students were delighted to see a copy and were unanimous in their view that this is a high quality bargain.

But what is essential haematology? As the authors acknowledge, the scope of the text is beyond the undergraduate curriculum, and those involved in medical education are trying desperately to teach ideas and method rather than detail to their hardpressed students. The amount of knowledge generated over the past 10 years in haematology is staggering and contains elements of molecular biology, immunology, and microbiology which had not even been thought of when the second edition was published. Hoffbrand and Pettit have decided to take the plunge and to teach haematology from a scientific basis, hoping that the able student will revel in the excitement of progress while the less able will be able to keep up because of the clarity of the material offered.

This is an outstanding attempt to summarise modern haematology and it will be a long time before a better book is published in this field, but the title is misleading. How about "A Short Textbook of Haematology-Science, Investigation and Clinical Practice"?

BT COLVIN

The Correspondence of Charles Darwin. Ed F Burkhardt, DM Porter, J Browne, M Richmond. (Pp 766; $£ 40 \cdot 00$.) Cambridge University Press. 1993. ISBN 0-521-44241-9

Anybody who is interested in Charles Darwin soon realises the complex nature of his personality. This was brought out very clearly in the voluminous biography by Adrian Desmond and James Moore (Michael Joseph 1991). It was "based on newly transcribed and unpublished letters", from which statement of the publishers it is obvious how important the enormous correspondence of Darwin and his contemporaries is for the understanding of scientific evolution in 19th century England. It is, therefore, not surprising that the present book is volume 8 of the correspondence of Charles Darwin. It covers almost exclusively the year 1860 which most observers have regarded as a watershed. At the beginning of January 1860 John Murray published the second edition of Darwin's Origin of Species, printing off another 3000 copies to satisfy an audience that surprised the publisher and the author.

On reading even only part of this correspondence, it becomes sadly obvious how much our present generation has lost of the skills of clarity and elegance of expression, of caustic wit, which does not lack politeness, in short, of the highest form of the art of communication. This also applies when Darwin merely pays the bill for books he ordered ( $p 56$ ). For students of Darwin the man, or for the period, the reading of the volumes of his correspondence is simply a must. For others, interested only in literature, it is a commendable pleasure.

VC MEDVEI

\section{Notices}

\section{Some new titles}

The receipt of books is acknowledged, and this listing must be regarded as sufficient return for the courtesy of the sender. Books that appear to be of particular interest will be reviewed as space permits.

Large Loop Excision of the Transformation Zone. A practical guide to LLETZ. Ed Walter Prendiville. (Pp 168; f60.) Chapman \& Hall. 1992.

\section{European Group for Breast Cancer Screening Annual Meeting}

18 September 1993

East Midlands Conference Centre, University of Nottingham

This meeting follows on immediately from the Nottingham-EORTC Joint Breast Cancer Meeting (14-17 September 1993). Preliminary programmes and registration forms are available from: Dr Robin Wilson, Nottingham National Breast Screening Training Centre, City Hospital, Nottingham NG5 1PB. Tel: 0602 691689. Fax: 0602627707.

\section{Royal College of Pathologists}

\section{Advances in the diagnosis of} myocardial infarction

Tuesday 21 September 1993, to be held at The Royal Society, 6 Carlton House Terrace, London SW 1.

\section{Current topics in veterinary} pathology

Wednesday 20 October 1993, to be held at The Royal College of Pathologists, 2 Carlton House Terrace, London SW 1 .

The meetings are open to members and non-members of the College. Further details and application forms can be obtained from Scientific Meetings Officer, RCPath, 2 Carlton House Terrace, London SW1Y 5AF. Tel: 0719305862 ext. $24 / 26$.

\section{Course on Cytopathology for} Histopathologists

31 January-4 February 1994 Northwick Park Hospital

This is an intensive course in cytopathology suitable for candidates preparing for the MRCPath examination in histopathology, and for established histopathologists requiring revision. It is given by the Department of Cellular Pathology, Northwick Park Hospital (Dr Elizabeth A Hudson) and the Department of Cytopathology, St Mary's Hospital Medical School, University of London (Professor Dulcie Coleman).

The programme will consist of lectures, microscopy sessions and discussions. Topics will include cytopathology of the cervix and of urine, the respiratory tract, serous effusions and fine needle aspiration cytology of breast and other sites. The course is limited to 30 participants. The course fee is $£ 250$ excluding accommodation.

Applications and enquiries should be made to: Dr Elizabeth Hudson, Department of Cellular Pathology, Northwick Park Hospital, Harrow, Middlesex HA1 3UJ. Tel: 081-869 3311 or 3312 .

Association of Clinical Pathologists Junior Membership

Junior membership of the Association is available to medical practitioners who have been engaged in the practice of pathology for a period of less than four years. Junior members are able to remain in this category for a maximum of six years or on the attainment of consultant status. The annual subscription is $£ 34$ for those resident in the United Kingdom and $£ 65$ for those overseas. The annual subscription may be claimed against tax. Junior members receive the fournal of Clinical Pathology each month. Other benefits are reduced registration fees to attend ACP scientific meetings, all the documents regularly sent to full members of the Association including $A C P$ News, which has a regular column for juniors, and the twice yearly summary of pathology courses included in the ACP programme of postgraduate education. Junior members have their own representative body, the Junior Members' Group, which has a direct input to Council. For Junior Membership apply to: The Honorary Secretary, Association of Clinical Pathologists, 221 Preston Road, Brighton BN1 6SA. (0273) 561188.

\section{Correction}

Sincere apologies are extended to $\mathrm{Mr}$ Agbarakwe, Effect of beta propiolactone on specific antibody measurements by ELISA f Clin Pathol 1993;46:368-9, for the errors which appeared in the above.

Mr Agbarakwe was incorrectly titled as Dr; the statistical program used was OXSTAT, not Amstrad; in the legend of figure 3, the units were $\mathrm{U} / \mathrm{ml}$ and not $\mathrm{IU} / \mathrm{ml}$, and finally, in reference 5 , it is, of course, pertussis vaccine and not pertsis vaccine as currently printed. 